\title{
The Effect of Obesogenic Environment and Socio- demographic Characteristics on Obesity Awareness Levels of Children
}

\section{Obezojenik Çevre ve Sosyo-demografik Özelliklerin Çocukların Obezite Farkındalık Düzeylerine Etkisi}

\author{
Arzu Sarıalioğlu* (0000-0003-3047-8008), Sibel Küçükoğlu** (0000-0003-3269-445X), Aynur Aytekin Özdemir** (0000-

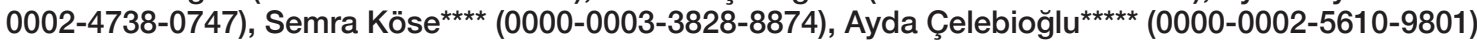 \\ ${ }^{*}$ Atatürk University Faculty of Nursing, Department of Child Health and Diseases Nursing, Erzurum, Turkey \\ **Selcuk University Faculty of Nursing, Department of Child Health and Diseases Nursing, Konya, Turkey \\ ***Istanbul Medeniyet University Faculty of Health Sciences, Department of Child Health and Diseases Nursing İstanbul, Turkey \\ ${ }^{\star * \star \star N e c m e t t i n ~ E r b a k a n ~ U n i v e r s i t y, ~ F a c u l t y ~ o f ~ N u r s i n g, ~ D e p a r t m e n t ~ o f ~ C h i l d ~ H e a l t h ~ a n d ~ D i s e a s e s ~ N u r s i n g, ~ K o n y a, ~ T u r k e y ~}$ \\ ${ }^{* * * \star *}$ Mersin University Faculty of Nursing, Department of Child Health and Diseases Nursing, Mersin, Turkey
}

Keywords

Child, nurse, obesity awareness, obesogenic environment

\section{Anahtar kelimeler \\ Çocuk, hemşire, obezite farkındalı ̆̆ obezojenik çevre}

Received/Geliş Tarihi : 01.07.2021

Accepted/Kabul Tarihi : 31.08 .2021

DOI:10.4274/jcp.2021.34603

Address for Correspondence/Yazışma Adresi: Arzu Sarıalioğlu, Atatürk University Faculty of Nursing, Department of Child Health and Diseases Nursing, Erzurum, Turkey

Phone: +90 4422315792

E-mail: arzu.celebi@atauni.edu.tr

\begin{abstract}
Introduction: The purpose of the study is to determine the effect of obesogenic environment and sociodemographic characteristics on children's obesity awareness levels.

Materials and Methods: The sample of the study was composed of a total of 540 children studying at the $5^{\text {th }}$ grade $(63), 6^{\text {th }}$ grade $(73)$, and $7^{\text {th }}$ grade $(79)$ in the private school and at the $5^{\text {th }}$ grade $(131), 6^{\text {th }}$ grade $(108)$, and $7^{\text {th }}$ grade (86) in the public school specified between the dates when the study was conducted. "Descriptive Information Form", "Obesogenic Environmental Evaluation Form (OEEF)" and "Obesity Awareness Scale (OAS)" were used to collect the data.

Results: It was determined that OEEF mean score was higher in children studying in the public school $(10.50 \pm 2.23)$ than those studying in the private school $(7.77 \pm 2.36)$ and the difference between them was significant. OAS "physical activity" subscale mean score was significantly higher in children studying in the public school.

Conclusion: When OEEF and OAS mean scores were examined according to sociodemographic variables, it was found that there was a significant difference between the groups in terms of some variables. It was determined in the study that the children studying in the public school were affected more by the obesogenic environmental conditions and gender increased the obesity awareness level of the children. Within the scope of the fight against obesity, it is recommended to conduct consciousness-raising and awareness programs related to obesogenic environment in all educational institutions primarily in public schools.
\end{abstract}

$\ddot{\mathbf{O} z}$

Giriş: Araştırmanın amacı, obezojenik çevre ve sosyodemografik özelliklerin çocukların obezite farkındalık düzeylerine etkisini belirlemektir.

Gereç ve Yöntem: Araştırmanın örneklemini çalışmanın yapıldı̆̆ı tarihlerde belirtilen özel okulda 5. sinıf (63), 6. sınıf (73), 7. sınıfta (79); devlet okulunda 5. sınıf (131), 6. sınıf (108), 7. sınıfta (86) eğitim gören toplam 540 çocuk oluşturdu. Araştırma verilerinin toplanmasında "Tanıtıcı Bilgi Formu", "Obezojenik Çevre Değerlendirme Formu (OÇDF)” ve “Obezite Farkındalık Ölçeği (OFÖ)” kullanıldı. 


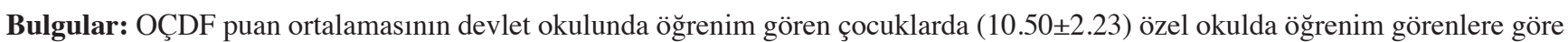
(7.77 \pm 2.36$)$ daha yüksek ve aradaki farkın anlamlı olduğu belirlendi ( $\mathrm{p}<0.05)$. OFÖ "fiziksel aktivite" alt boyutu puan ortalaması devlet okulunda öğrenim gören çocuklarda anlamlı şekilde daha yüksek bulundu $(\mathrm{p}<0.05)$.

Sonuç: OÇDF ve OFÖ puan ortalamaları sosyodemografik değişkenlere göre incelendiğinde bazı değişkenler açısından gruplar arasında anlamlı fark olduğu belirlendi. Çalışmada obezojenik çevre koşullarından devlet okulunda öğrenim gören çocukların daha fazla etkilendiği, cinsiyetin çocukların obezite farkındalık düzeyini artırdığı saptandı. Obezite ile mücadele kapsamında öncelikli olarak devlet okulları olmak üzere, tüm eğitim kurumlarında obezojenik çevre ile ilgili bilinçlendirme ve farkındalık oluşturma programlarının yürütülmesi önerilir.

\section{Introduction}

Obesity is an important health problem that can cause social, psychological and many medical problems arising from the pathological increase of adipose tissue in proportion to body weight in the cases where the energy intake is more than energy consumption (1). Obesity is not only a chronic disease that negatively affects quality of life and life expectancy but it is also an important health problem of the developing world (2). Obesity is a serious public health problem with an increasing prevalence worldwide. According to the data of the World Health Organization, $6 \%$ of girls and $8 \%$ of boys in age group of 5-19 years were obese in 2016 (3). The childhood obesity starts frequently in the first year of life, the ages of 5-6 years, and adolescence period (1).

In the development of obesity, heredity, intrauterine factors, diet, culture, environmental factors and psychological factors play a role (1). There are many factors that are responsible for the etiology of obesity. One of these factors is the "obesogenic environment" (causing obesity, gaining weight) supported by overeating and immobility $(4,5)$. The studies conducted about increasing childhood obesity have showed that obesogenic environment and behaviors are an important factor for obesity $(4,6)$. Although dietary options and nutrition environment supporting obesity are regarded as an environmental contribution to obesity, the rapid increase in global obesity rates is associated with the obesogenic environment $(7,8)$.

It is important that people have high awareness against factors causing obesity such as obesogenic environment. In terms of social psychology, "Awareness is a term used to indicate how much people are aware of their attitudes and behaviors". As awareness increases, behaviors appropriate to attitudes increase. It is used in various ways in daily life such as psychological awareness, political awareness, legal awareness, awareness about environmental issues, obesity awareness, and women's rights awareness. In this way, problems are handled by raising both individual and mass awareness from general areas to specific and certain issues, measurements are performed and briefly, the society is tried to be changed (9). In recent years, the number of studies investigating the obesity awareness has increased. In their study, Murphy and Polivka (10) reported the awareness of parents of school-age children about obesity and body mass index and more than $80 \%$ of the participants reported immobility, malnutrition, lack of control in the children's diet and overeating as the main causes of obesity. In their study, Fahlman et al. (11) assessed the effect of Michigan Model, an education program about nutrition applied to secondary school students, on their eating habits and awareness and found that it caused significant positive changes in both eating knowledge and behaviors of children. Lee et al. (12) investigated the physical activity perception of students by applying a physical activity program to obese students and found results helping them to better understand their exercise perception. Washington et al. (13) investigated the effect of ecological factors and family in normal and overweight children in preschool period and found that they were effective. In their study, Atl et al. (14) investigated obesity awareness of secondary school students and they found a significant difference between body mass index and gender. In their study, Sözen and Bebek (15) examined the obesity awareness of university students and found that women had more obesity awareness than men.

In terms of community health, children's body weight and weight gain tendency should be carefully monitored by healthcare professionals in routine health checks, families should be informed about this issue and necessary measures should be taken (1). In this regard, nurses have an important position in the management of childhood obesity. Nursing approach in obesity management is multidimensional and 
includes physical, social, and emotional evaluation of the child and his/her family such as health promotion, increasing physical activity, measuring body mass index, height and weight follow up, determining family practices affecting the food intake of the child, being sensitive to family needs, and collaborating with family (16-18).

In the studies on obesity, physical aspect of obesity is generally focused and psychosocial factors are ignored. Number of studies examining the obesogenic environment and obesity awareness levels is still insufficient today. In this respect, the study was designed to determine the effect of obesogenic environment and sociodemographic characteristics on the obesity awareness levels of children.

\section{Material and Methods}

\section{Setting and Sample}

This descriptive study was conducted in a public primary school and a private primary school in Erzurum city between May and June 2017. The population of the study was composed of children studying in primary schools in Erzurum city. The primary schools in city center of Erzurum were stratified as public and private schools in terms of socioeconomic aspect. Selecting a school from each stratum and including it in the study were conducted by using simple random sampling method. The sample of the study was composed of all of $5^{\text {th }}, 6^{\text {th }}$ and $7^{\text {th }}$ graders $(n=550)$ studying in the public and private schools determined. Since institution and parent permissions could not be obtained for participation of $8^{\text {th }}$ grade students due to their preparation for high school exam in Turkey, the study was conducted with $5^{\text {th }}, 6^{\text {th }}$ and $7^{\text {th }}$ grade students. As a result of the power analysis conducted in the study, when 535 students were included in the study, it was determined that its size effect was 0.141 , power was $95 \%$ and $\alpha$ type error estimation was 0.05 . By predicting that there would be losses, 550 students were included in the study and the study was completed with 540 students. This number pointed out that the sample size was adequate (19).

\section{Measurement}

The "Descriptive Information Form", "Obesogenic Environmental Evaluation Form", and "Obesity Awareness Scale" were used to collect the data of the study.

\section{Introductory Information Form}

This form, prepared by the researchers based on literature (20-22), is composed of questions about the children's age, gender, height, weight, school, grade, family type, socioeconomic level, mothers' age, educational background and occupation, and fathers' age, educational background and occupation

\section{Obesogenic Environmental Evaluation Form}

Obesogenic Environmental Evaluation Form is a questionnaire prepared by Yayan and Çelebioğlu (22) in order to determine obesogenic properties of the environment where the child lives. The form includes 20 questions evaluating the child's school, neighborhood and home environments in terms of obesogenic properties. In the form, all responses including obesogenic environment properties get 1 point. Accordingly, some questions are reversely scored. While the highest score that can be taken from the form is 20 , the lowest score is 0 . High score signifies that the child lives in an obesogenic environment (22).

\section{Obesity Awareness Scale}

Obesity Awareness Scale was developed by Allen in 2011 to measure obesity awareness in children. The original version of the scale has 23 items and three subscales. The subscales of the scale are obesity awareness, nutrition, and physical activity. The scale has a 4-point Likert type scale from negative to positive (23). Turkish validity and reliability study of OAS was conducted by Kafkas and Özen in 2014. The Turkish version of the scale consists of 20 items and three subscales. The highest score to be taken from the scale is 80 ; whereas, its lowest score is 20 . High score indicates obesity awareness. Cronbach's Alpha reliability coefficient of the scale was determined as 0.87 (20). In this study, the Cronbach's alpha coefficient of the scale was found as 0.82 . This value shows that the scale has a high reliability.

\section{Data Collection}

The data were collected in accordance with the work schedule prepared by the school management by considering the syllabus of all $5^{\text {th }}, 6^{\text {th }}$, and $7^{\text {th }}$ grades in both schools between May and June 2017. According to this schedule, the data collection forms were applied to the students in the classroom environment 
at the time determined for each class after making the necessary explanations about the forms. It took about 20-30 minutes to complete this process.

\section{Ethical Considerations}

Before starting the study, ethical approval from Ethics Committee (2017/3-11), official permission from the Ministry of National Education, written consents from the parents of the children and verbal consents from the children were obtained. "Informed Consent Form" which was prepared for the purpose of obtaining written consents of the parents of the children were distributed in closed envelopes to the parents through their children and their written consents were obtained. Before applying the data collection forms, the children were informed about purpose and benefits of the study and their verbal consents were obtained so that their participation in the study was ensured.

\section{Data Analysis}

The data was assessed in the computer environment with SPSS (Statistical Package for Social Sciences) 20.0 package program. Number, percentages, minimum and maximum values and mean and standard deviation were used in the data analysis, and Kurtosis and skewness coefficients were used to determine the compatibility of data to normal distribution. Independent samples t-test and Anova (for normally distributed data) and Mann Whitney-U test and Kruskal-Wallis test (for non-normally distributed data) were used. Cronbach's alpha coefficient calculation, power analysis and Tukey and Dunnett's-C analysis as advanced analysis were used. Significance level was accepted as $\mathrm{p}<0.05$.

\section{Results}

When the descriptive characteristics of the children were examined, it was determined that $59.1 \%$ of the children studying in the private school were in the age group of $10-12$ years, $58.1 \%$ were boy, $36.7 \%$ were $7^{\text {th }}$ graders, $90.2 \%$ were the members of a nuclear family, $87.4 \%$ expressed their socioeconomic status as high, $70.7 \%$ of their mothers had a bachelor's degree and $52.1 \%$ of them were employed, $86.5 \%$ of their fathers had a bachelor's degree and $63.2 \%$ were involved in the civil servant/worker group. For the children studying in the public school, it was determined that
$68.6 \%$ of the children were in the age group of 10 12 years, $51.7 \%$ were girl, $40.3 \%$ were $5^{\text {th }}$ graders, $78.8 \%$ were the members of a nuclear family, $65.8 \%$ expressed their socioeconomic status as high, $51.1 \%$ of their mothers had primary school degree and $89.5 \%$ of them were unemployed, $45.5 \%$ of their fathers had secondary school degree and $54.5 \%$ of them were involved in the civil servant/worker group (Table 1).

In the study, it was found that obesogenic environmental evaluation form mean score was higher in the children studying in the public school and the difference between them was statistically significant $(p<0.05)$. Although OAS mean scores were higher in children studying in the private school, the result was not statistically significant $(\mathrm{p}>0.05)$. OAS physical activity subscale mean score was significantly higher in children studying in the public school $(\mathrm{p}<0.05$, Table 2).

When OEEF mean scores of the children were compared according to age groups, a significant difference was determined between the groups $(p<0.05)$. As a result of the advanced analyses, the significance was found between the children in both age groups studying in the private school and the children in both age groups studying in the public school (Table 3).

When OEEF mean scores of the children were compared in terms of gender in the study, a significant difference was found between the groups $(\mathrm{p}<0.05)$. As a result of the advanced analyses, the significant difference between the groups was determined between the girls studying in the private school and the boys and girls studying in the public school (Table 3 ).

It was found in the study that OEEF mean scores of children in all grade levels of the public school were higher than those in the private school and this difference between the groups was statistically significant $(\mathrm{p}<0.05)$. As a result of the advanced analyses, the significant difference between the groups was determined between children studying at all grade levels in the private school and the children studying at all grade levels in the public school (Table 3).

When OEEF mean scores were compared in terms of family types, it was found that there was a significant difference between the groups $(p<0.05)$. As a result of the advanced analyses, it was determined that the significance between the groups was present between the children, who were studying in the private school 
Table 1. Distribution according to descriptive characteristics of the children

\begin{tabular}{|c|c|c|c|c|}
\hline \multirow{2}{*}{ Descriptive characteristics } & \multicolumn{2}{|c|}{ Private school $(\mathrm{n}=215)$} & \multicolumn{2}{|c|}{ Public school (n=325) } \\
\hline & $\mathrm{n}$ & $\%$ & $\mathrm{n}$ & $\%$ \\
\hline \multicolumn{5}{|l|}{ Age } \\
\hline $10-12$ age & 127 & 59.1 & 223 & 68.6 \\
\hline $13-15$ age & 88 & 40.9 & 102 & 31.4 \\
\hline \multicolumn{5}{|l|}{ Gender } \\
\hline Girl & 90 & 41.9 & 168 & 51.7 \\
\hline Boy & 125 & 58.1 & 157 & 48.3 \\
\hline \multicolumn{5}{|l|}{ Class } \\
\hline 5th graders & 63 & 29.3 & 131 & 40.3 \\
\hline 6th graders & 73 & 34.0 & 108 & 33.2 \\
\hline 7th graders & 79 & 36.7 & 86 & 26.5 \\
\hline \multicolumn{5}{|l|}{ Family type } \\
\hline Nuclear family & 194 & 90.2 & 256 & 78.8 \\
\hline Extended family & 21 & 9.8 & 69 & 21.2 \\
\hline \multicolumn{5}{|l|}{ Socio-economic situation } \\
\hline High & 188 & 87.4 & 214 & 65.8 \\
\hline Middle & 27 & 12.6 & 111 & 34.2 \\
\hline \multicolumn{5}{|c|}{ Mother's educational background } \\
\hline Primary school & & & 166 & 51.1 \\
\hline Secondary school & $\begin{array}{l}11 \\
52\end{array}$ & 24.1 & 119 & 36.6 \\
\hline Faculty & 152 & 70.7 & 40 & 12.3 \\
\hline \multicolumn{5}{|l|}{ Mother's employment status } \\
\hline Employed & 112 & 52.1 & 34 & 10.5 \\
\hline Unemployed & 103 & 47.9 & 291 & 89.5 \\
\hline \multicolumn{5}{|c|}{ Father's educational background } \\
\hline Primary school & 5 & 2.3 & 54 & 16.6 \\
\hline Secondary school & $\begin{array}{l}5 \\
24\end{array}$ & 11.2 & 148 & 45.5 \\
\hline Faculty & 186 & 86.5 & 123 & 37.9 \\
\hline \multicolumn{5}{|l|}{ Father's occupition } \\
\hline Unemployed & 4 & 1.8 & 11 & 3.4 \\
\hline Civil servant/worker & 136 & 63.2 & 177 & 54.5 \\
\hline Self-employment & 70 & 32.5 & 117 & 36.0 \\
\hline Retired & 5 & 1.5 & 20 & 6.1 \\
\hline
\end{tabular}

Table 2. Comparison of children's OEEF and OAS mean scores

\begin{tabular}{lllll}
\hline Scales & $\begin{array}{l}\text { Private School } \\
\text { Mean } \pm \text { SD }\end{array}$ & $\begin{array}{l}\text { Public School } \\
\text { Mean } \pm \text { SD }\end{array}$ & $\mathrm{t}$ & $\mathrm{p}$ \\
\hline OEEF & $7.77 \pm 2.36$ & $10.50 \pm 2.23$ & -13.566 & $\mathbf{0 . 0 0 0}$ \\
Obesity awareness total grade & $57.38 \pm 10.49$ & $55.89 \pm 9.45$ & 1.711 & 0.088 \\
Obesity awareness sub-dimension & $21.95 \pm 4.77$ & $21.22 \pm 4.41$ & 1.828 & 0.068 \\
Nutrition sub-dimension & & & & \\
Physical sub-dimension & $21.63 \pm 4.40$ & $21.50 \pm 3.90$ & 0.367 & 0.714 \\
\hline OEEF: Obesogenic Environmental Evaluation Form & $13.10 \pm 5.50$ & $14.25 \pm 5.85$ & -2.252 & $\mathbf{0 . 0 2 5}$ \\
\hline
\end{tabular}

and living in the nuclear and extended families, and the children who were studying in public school and living in nuclear and extended families (Table $3)$. 
Table 3. Comparison of OEEF mean scores according to descriptive characteristics of the children

\begin{tabular}{|c|c|c|c|}
\hline Descriptive characteristics & $\begin{array}{l}\text { Private school }(n=215) \\
\text { Mean } \pm \text { SD }\end{array}$ & $\begin{array}{l}\text { Public school }(n=325) \\
\text { Mean } \pm \text { SD }\end{array}$ & Test and $\mathrm{p}$ \\
\hline $\begin{array}{l}\text { Age } \\
10-12 \text { age } \\
13-15 \text { age } \\
\text { Test and p }\end{array}$ & $\begin{array}{l}7.45 \pm 2.25 \\
8.23 \pm 2.45 \\
t=-2.410 / p=\mathbf{0 . 0 1 7}\end{array}$ & $\begin{array}{l}10.26 \pm 2.21 \\
11.01 \pm 2.18 \\
t=-2.864 / p=\mathbf{0 . 0 0 4}\end{array}$ & $\begin{array}{l}F=67.397 \\
p=\mathbf{0 . 0 0 0}\end{array}$ \\
\hline $\begin{array}{l}\text { Gender } \\
\text { Girl } \\
\text { Boy } \\
\text { Test and p }\end{array}$ & $\begin{array}{l}7.76 \pm 2.27 \\
7.78 \pm 2.43 \\
t=-0.053 / p=0.958\end{array}$ & $\begin{array}{l}10.67 \pm 2.26 \\
10.31 \pm 2.18 \\
t=1.483 / p=0.139\end{array}$ & $\begin{array}{l}F=62.052 \\
p=\mathbf{0 . 0 0 0}\end{array}$ \\
\hline $\begin{array}{l}\text { Class } \\
5^{\text {th }} \text { graders } \\
6^{\text {th }} \text { graders } \\
7^{\text {th }} \text { graders } \\
\text { Test and } \mathbf{p}\end{array}$ & $\begin{array}{l}7.00 \pm 2.01 \\
7.76 \pm 2.33 \\
8.40 \pm 2.49 \\
\mathrm{~F}=6.503 / \mathrm{p}=\mathbf{0 . 0 0 2}\end{array}$ & $\begin{array}{l}10.01 \pm 2.13 \\
10.67 \pm 2.37 \\
11.02 \pm 2.05 \\
\mathrm{~F}=5.976 / \mathrm{p}=\mathbf{0 . 0 0 3}\end{array}$ & $\begin{array}{l}F=43.314 \\
p=\mathbf{0 . 0 0 0}\end{array}$ \\
\hline $\begin{array}{l}\text { Family type } \\
\text { Nuclear family } \\
\text { Extended family } \\
\text { Test and p } \\
\end{array}$ & $\begin{array}{l}7.80 \pm 2.34 \\
7.52 \pm 2.56 \\
U=1868.000 / p=0.529\end{array}$ & $\begin{array}{l}10.46 \pm 2.21 \\
10.65 \pm 2.28 \\
t=-0.632 / p=0.474\end{array}$ & $\begin{array}{l}\mathrm{KW}=134.971 \\
\mathrm{p}=\mathbf{0 . 0 0 0}\end{array}$ \\
\hline $\begin{array}{l}\text { Socio-economic situation } \\
\text { High } \\
\text { Middle } \\
\text { Test and p }\end{array}$ & $\begin{array}{l}7.77 \pm 2.31 \\
7.81 \pm 2.76 \\
t=1.173 / p=0.556\end{array}$ & $\begin{array}{l}10.56 \pm 2.22 \\
10.37 \pm 2.23 \\
t=0.717 / p=0.543\end{array}$ & $\begin{array}{l}\mathrm{KW}=116.336 \\
\mathrm{p}=\mathbf{0 . 0 0 0}\end{array}$ \\
\hline $\begin{array}{l}\text { Mother's educational back } \\
\text { Primary school } \\
\text { Secondary school } \\
\text { Faculty } \\
\text { Test and p }\end{array}$ & $\begin{array}{l}7.81 \pm 1.94 \\
7.96 \pm 2.46 \\
7.71 \pm 2.36 \\
\mathrm{KW}=1.302 / \mathrm{p}=0.729\end{array}$ & $\begin{array}{l}10.36 \pm 2.16 \\
10.67 \pm 2.34 \\
10.57 \pm 2.19 \\
K W=0.922 / p=0.820\end{array}$ & $\begin{array}{l}\mathrm{KW}=113.467 \\
\mathrm{p}=\mathbf{0 . 0 0 0}\end{array}$ \\
\hline $\begin{array}{l}\text { Mother's employment stat } \\
\text { Employed } \\
\text { Unemployed } \\
\text { Test and p }\end{array}$ & $\begin{array}{l}7.66 \pm 2.49 \\
7.89 \pm 2.22 \\
t=-0.691 / p=0.490\end{array}$ & $\begin{array}{l}10.67 \pm 1.75 \\
10.47 \pm 2.29 \\
t=0.598 / p=0.552\end{array}$ & $\begin{array}{l}F=60.501 \\
p=\mathbf{0 . 0 0 0}\end{array}$ \\
\hline $\begin{array}{l}\text { Father's educational backg } \\
\text { Primary school } \\
\text { Secondary school } \\
\text { Faculty } \\
\text { Test and p }\end{array}$ & $\begin{array}{l}7.20 \pm 2.28 \\
8.58 \pm 2.33 \\
7.68 \pm 2.36 \\
K W=3.730 / p=0.155\end{array}$ & $\begin{array}{l}10.03 \pm 2.20 \\
10.50 \pm 2.22 \\
10.70 \pm 2.22 \\
K W=3.768 / p=0.288\end{array}$ & $\begin{array}{l}\mathrm{KW}=134.602 \\
\mathrm{p}=\mathbf{0 . 0 0 0}\end{array}$ \\
\hline $\begin{array}{l}\text { Father's occupition } \\
\text { Unemployed } \\
\text { Civil servant/worker } \\
\text { Self-employment } \\
\text { Retired } \\
\text { Test and p }\end{array}$ & $\begin{array}{l}10.00 \pm 0.00 \\
7.44 \pm 2.42 \\
8.50 \pm 2.16 \\
6.60 \pm 0.50 \\
K W=13.805 / p=0.303\end{array}$ & $\begin{array}{l}10.16 \pm 1.72 \\
10.22 \pm 2.26 \\
10.78 \pm 2.20 \\
11.40 \pm 2.13 \\
K W=7.318 / p=0.062\end{array}$ & $\begin{array}{l}\mathrm{KW}=145.578 \\
\mathrm{p}=\mathbf{0 . 0 0 0}\end{array}$ \\
\hline
\end{tabular}

When OEEF mean scores were compared in terms of socioeconomic status, it was determined that there was a significant difference between the groups and the difference was observed between the children in both groups studying in the private school and the children in both groups studying in the public school $(\mathrm{p}<0.05$, Table 3$)$. 
Mothers' educational background was found to be effective on OEEF mean scores $(\mathrm{p}<0.05)$. As a result of the advanced analyses, the significant difference between the groups was found to be between the children in all three groups studying in the private school and the children in all three groups studying in the public school (Table 3 ).

When OEEF mean scores were compared in terms of mothers' employment status, it was found that there was a significant difference between the groups $(p<0.05)$. As a result of the advanced analyses, the significant difference between the groups was found between the children, who were studying in the private school and had employed and unemployed mothers, and the children, who were studying in the public school and had employed and unemployed mothers (Table 3).

Similarly, when OEEF mean scores were compared in terms of fathers' educational background, it was determined that there was a significant difference between the groups $(\mathrm{p}<0.05)$. As a result of the advanced analyses, the significant difference between the groups was determined between the children, who were studying in the private school and had father with secondary school degree and bachelor's degree, and the children, who were studying in the public school and had fathers with primary, secondary school and bachelor's degree, (Table 3).

When OEEF mean scores were compared according to the fathers' occupation, a significant difference was determined between the groups $(\mathrm{p}<0.05)$. As a result of the advanced analysis, the significant difference between the groups was found between the children in all groups studying in the private school and the children who were studying in the public school and had civil servant, self-employed and retired fathers (Table 3).

When OAS mean scores were compared in terms of descriptive characteristics of the children, it was revealed that variables such as age, grade, family type, socioeconomic status, mothers' education level and employment status, and fathers' education level and profession were not effective on OAS mean scores of the children $(\mathrm{p}>0.05)$. When OAS mean scores were compared in terms of the gender of children, it was determined that there was a significant difference between the groups and the difference between the groups was determined between the boys in the private school and public school and the boys and girls in the public school $(\mathrm{p}<0.05$, Table 4$)$.

\section{Discussion}

Obesity is an important health problem that can result in social, psychological and many medical problems (1). The studies conducted on increasing childhood obesity have showed that obesogenic environment and behaviors is an important factor for obesity $(4,6)$.

In the study, obesogenic environmental characteristics of the children studying in the private and public schools were evaluated with OEEF and the mean score of the children studying in the private school $(7.77 \pm 2.36)$ was lower than the mean score of the children studying in the public school (10.50 \pm 2.23 ) (Table 2). This result showed that the living spaces of children studying in the public school had more obesogenic properties. When the literature was examined, no study was found investigating the environments of the children in the public and private schools from an obesogenic perspective. In the study conducted by Yayan and Çelebioğlu (22) to investigate the "effect of obesogenic environment and social support for health behaviors on body mass index and body image of adolescents", they determined that obesogenic environment mean score $(13.10 \pm 2.75)$ was higher than the mean score obtained in this study. When the items of OEEF were examined, it can be asserted that there was a difference between the private schools and public schools in the city center of Erzurum in terms of sportive activity areas. In terms of the areas of sports activities and opportunities for activities in the school campus, private schools provided more advantages to children. In relation to this, it can be thought that the school environment of the children in the public school had more obesogenic properties. Sedentary lifestyle and low physical activity level cause overweight and obesity in childhood (24). Overweight in children and adolescents is generally caused by low physical activity and unhealthy diet resulting in excessive energy intake (25). The result of the study is a striking finding, especially in terms of showing that the environments of children studying in the public school should be examined more from obesogenic aspect.

In the study, it was found that OAS mean score of children in the private school was higher than the 
Table 4. Comparison of OAS mean scores according to descriptive characteristics of the children

\begin{tabular}{|c|c|c|c|}
\hline Descriptive characteristics & $\begin{array}{l}\text { Private school }(n=215) \\
\text { Mean } \pm \text { SD }\end{array}$ & $\begin{array}{l}\text { Public school }(n=325) \\
\text { Mean } \pm \text { SD }\end{array}$ & Test and $\mathrm{p}$ \\
\hline $\begin{array}{l}\text { Age } \\
10-12 \text { age } \\
13-15 \text { age } \\
\text { Test and p }\end{array}$ & $\begin{array}{l}57.89 \pm 9.90 \\
56.63 \pm 11.30 \\
t=0.866 / p=0.387\end{array}$ & $\begin{array}{l}55.75 \pm 9.23 \\
56.20 \pm 9.95 \\
t=-0.400 / p=0.689\end{array}$ & $\begin{array}{l}\mathrm{F}=1.305 \\
\mathrm{p}=0.272\end{array}$ \\
\hline $\begin{array}{l}\text { Gender } \\
\text { Girl } \\
\text { Boy } \\
\text { Test and p }\end{array}$ & $\begin{array}{l}57.11 \pm 8.84 \\
57.57 \pm 11.56 \\
t=-0.320 / p=0.749\end{array}$ & $\begin{array}{l}57.32 \pm 9.00 \\
54.36 \pm 9.70 \\
t=2.844 / p=\mathbf{0 . 0 0 5}\end{array}$ & $\begin{array}{l}F=3.465 \\
p=\mathbf{0 . 0 1 6}\end{array}$ \\
\hline $\begin{array}{l}\text { Class } \\
5^{\text {th }} \text { graders } \\
6^{\text {th }} \text { graders } \\
7^{\text {th }} \text { graders } \\
\text { Test and } \mathbf{p}\end{array}$ & $\begin{array}{l}57.12 \pm 9.89 \\
57.71 \pm 10.41 \\
57.27 \pm 11.13 \\
\mathrm{~F}=0.058 / \mathrm{p}=0.944\end{array}$ & $\begin{array}{l}55.30 \pm 8.47 \\
56.23 \pm 10.39 \\
56.37 \pm 9.68 \\
\mathrm{~F}=0.431 / \mathrm{p}=0.650\end{array}$ & $\begin{array}{l}F=0.766 \\
p=0.574\end{array}$ \\
\hline $\begin{array}{l}\text { Family type } \\
\text { Nuclear family } \\
\text { Extended family } \\
\text { Test and p }\end{array}$ & $\begin{array}{l}57.37 \pm 10.56 \\
57.42 \pm 10.05 \\
U=1938.000 / p=0.714\end{array}$ & $\begin{array}{l}55.93 \pm 8.95 \\
55.73 \pm 11.18 \\
t=0.154 / p=0.892\end{array}$ & $\begin{array}{l}\mathrm{KW}=6.251 \\
\mathrm{p}=0.100\end{array}$ \\
\hline $\begin{array}{l}\text { Socio-economic situation } \\
\text { High } \\
\text { Middle } \\
\text { Test and p }\end{array}$ & $\begin{array}{l}57.33 \pm 10.81 \\
57.70 \pm 8.05 \\
t=0.377 / p=0.828\end{array}$ & $\begin{array}{l}56.44 \pm 9.79 \\
54.83 \pm 8.70 \\
t=1.455 / p=0.147\end{array}$ & $\begin{array}{l}\mathrm{KW}=2.474 \\
\mathrm{p}=0.290\end{array}$ \\
\hline $\begin{array}{l}\text { Mother's educational background } \\
\text { Primary school } \\
\text { Secondary school } \\
\text { Faculty } \\
\text { Test and p }\end{array}$ & $\begin{array}{l}50.18 \pm 13.03 \\
57.57 \pm 10.72 \\
57.83 \pm 10.09 \\
\mathrm{KW}=4.523 / \mathrm{p}=0.210\end{array}$ & $\begin{array}{l}56.25 \pm 9.68 \\
54.89 \pm 9.45 \\
57.35 \pm 8.33 \\
\mathrm{KW}=3.838 / \mathrm{p}=0.279\end{array}$ & $\begin{array}{l}\mathrm{KW}=7.314 \\
\mathrm{p}=0.063\end{array}$ \\
\hline $\begin{array}{l}\text { Mother's employment status } \\
\text { Employed } \\
\text { Unemployed } \\
\text { Test and p }\end{array}$ & $\begin{array}{l}58.44 \pm 9.12 \\
56.22 \pm 11.73 \\
t=1.557 / p=0.121\end{array}$ & $\begin{array}{l}54.64 \pm 11.49 \\
58.06 \pm 9.14 \\
t=-0.833 / p=0.406\end{array}$ & $\begin{array}{l}F=2.068 \\
p=0.103\end{array}$ \\
\hline $\begin{array}{l}\text { Father's educational background } \\
\text { Primary school } \\
\text { Secondary school } \\
\text { Faculty } \\
\text { Test and p }\end{array}$ & $\begin{array}{l}60.60 \pm 4.44 \\
57.70 \pm 5.78 \\
57.25 \pm 11.06 \\
\mathrm{KW}=0.435 / \mathrm{p}=0.805\end{array}$ & $\begin{array}{l}53.33 \pm 9.53 \\
56.33 \pm 9.42 \\
56.48 \pm 9.33 \\
\mathrm{KW}=2.999 / \mathrm{p}=0.392\end{array}$ & $\begin{array}{l}\mathrm{KW}=10.358 \\
\mathrm{p}=0.160\end{array}$ \\
\hline $\begin{array}{l}\text { Father's occupition } \\
\text { Unemployed } \\
\text { Civil servant/worker } \\
\text { Self-employment } \\
\text { Retired } \\
\text { Test and p }\end{array}$ & $\begin{array}{l}58.50 \pm 6.36 \\
58.11 \pm 10.42 \\
56.15 \pm 10.32 \\
52.80 \pm 17.12 \\
\mathrm{KW}=1.596 / \mathrm{p}=0.660\end{array}$ & $\begin{array}{l}55.33 \pm 5.04 \\
56.84 \pm 9.53 \\
55.66 \pm 8.75 \\
50.20 \pm 11.85 \\
\mathrm{KW}=6.550 / \mathrm{p}=0.088\end{array}$ & $\begin{array}{l}\mathrm{KW}=13.219 \\
\mathrm{p}=0.067\end{array}$ \\
\hline
\end{tabular}

mean score of the children studying in the public school (Table 2). There are a limited number of studies in literature investigating the obesogenic awareness levels of students studying in private and public schools.
Among these studies, the Obesogenic Awareness Scale general mean score determined in the study by Atl 1 et al. (14) is similar to the score received by the students studying in the private school in the present study 
(58.28 \pm 8.66$)$. The fact that the children studying in the private school had higher obesity awareness may be associated with their living standards, school facilities and awareness of their parents.

When OEEF mean scores of the children studying in the public and private schools were examined in terms of age groups and grade levels in the study, it was found that there was a significant difference between the groups and as the age of children increased, their mean scores increased (Table 3 ). In the study by Yayan and Çelebioğlu (22), it was found that age affected OEEF mean score and as the age of adolescents increased, their mean scores increased. The result of the study showed that as the age of the children increased, their tendency to obesogenic environment increased.

When OEEF and OAS mean scores of the children studying in the public and private schools were examined in terms of gender in the study, it was determined that there was a significant difference between the groups (Table 3,4). The significant difference for OEEF was caused by the lower mean score of girls studying in the private school. In their study, Çınar and Çavuşoğlu (26) examined the obesity condition according to gender and found that male students had a higher rate of obesity than female students and the difference between male and female students in terms of obesity was statistically significant. Likewise, in another study, Özilbey et al. (27) examined obesity prevalence and eating habits in primary school students in two private and two public schools. As a result of the regression analysis, the obesity rate was found to be higher in boys with high income level. This result in the study suggest that girls paid more attention to body image caused by the fact that girls paid more attention to obesogenic environmental conditions and obesity was seen less. The significant difference for OAS was caused by higher mean score of boys studying in the private school. Atl1 et al. (14) found in their study that girls had higher subscales and scale mean scores compared to boys but there was no significant difference. This difference in the study suggested that boys studying in the private school had high obesity awareness.

When OEEF mean scores were examined in terms of family types in the study, a significant difference was determined between the groups and this difference was due to the higher mean score of children studying in the public school (Table 3). In their study, Yayan and
Çelebioglu (22) found that obesogenic environmental mean score of adolescents living in the nuclear family was higher but the difference was not found to be statistically significant. Different results of the study may be due to the reasons such as decreased control of families on their children because of high number of individuals in extended family and failure to monitor where, when and what type of food the children eat.

In the study, when OEEF mean scores were examined in terms of socioeconomic status, a significant difference was determined between the groups and this difference was caused by higher mean score of the children in the public school (Table 3 ). When the literature is reviewed, there is an inverse correlation between socioeconomic status and obesity (28). It is known that in the countries with low national income per capita, children do not eat healthy and measures to protect children from obesity are not taken sufficiently in schools and family (29). Likewise, it is stated that while environmental factors of children living in neighborhoods with low-income support their energy intake, there is insufficient or little opportunities for their expenses (30). In a study investigating "the effect of eating behaviors of primary school students and the eating style of parents on childhood obesity", more obesity was observed in the school with a moderate and high socio-economic level compared to the school with low socio-economic level (21). In a study conducted by Alphan et al. (31) in 2002 to compare eating habits of adolescents studying in the private and public schools, malnutrition was determined to be higher in students with low socioeconomic status. In 299 children aged between 6-15 years at a primary school with high socio-economic level in 2003 in Bakırköy, Istanbul, it was determined that the obesity prevalence was $8.4 \%$ and overweight prevalence was $26.7 \%$ (32). In the study by Atl1 et al. (31) obesity increase was found to be higher in schools with high socioeconomic level. Different study results may be associated with the fact that the opportunities provided to children studying in private schools are better (health eating conditions, high number of sportive activities, etc.), families with high income level generally have high education level and are aware of the obesogenic environment.

In the study, when OEEF mean scores were examined in terms of education level and employment status of parents, it was found that there was a significant difference between the groups and this 
difference was due to the higher mean scores of children studying in the public school (Table 3). When the literature is examined, the status and education of mothers is an effective factor on conscious and correct behavior of children in food consumption. It was found out that there was a positive correlation between the education level of mothers and the importance of nutrition and the growth and development of the child (33). Likewise, in the study by Alphan et al. (31), they detected that education levels of mothers of students studying in a private school were high and these children had balanced diet. Since parents who have insufficient knowledge about nutrition education have no idea how children should be fed, body composition of the child deteriorates (34). In the study by Yayan and Çelebioğlu (22), it was found that mothers' education level and working status had an effect on OEEF mean score but fathers' education level and working status did not affect OEEF mean score. The study result may be caused by higher awareness levels of parents of children studying in the private school since their education level and working status were generally higher compared to the parents of children studying in the public school.

\section{Study Limitations}

At the time of the survey as they prepare for the high school exams in Turkey lack of 8th grade students to participate in research studies is limited.

\section{Conclusions}

It was determined in the study that children studying in the public school were more affected by obesogenic environment conditions and gender increased the obesity awareness level of children. Within the scope of the fight with obesity, it is recommended to carry out consciousness-raising and awareness programs related to obesogenic environment in all educational institutions, primarily in public schools.

Providing holistic education and awareness efforts including family, school, children and the people who interact with children about healthy nutrition and importance of physical activity, strengthening the policies related to this issue, monitoring the growth including weight and height follow-up from birth and maintaining and evaluating the growth until the end of adolescence period are important approaches.

\section{Ethics}

$* 6^{\text {th }}$ National 1st International Pediatrics Nursing Congress, 29 November-2 December 2017, Antalya Ethics Committee Approval: This study received 17/04/2017 dated and 2017-3/11 numbered approval was taken from Erzurum Atatürk University Faculty of Health Sciences Ethical Board.

Conflict of Interest: No conflict of interest was declared by the authors.

Financial Disclosure: The authors declared that this study received no financial support.

\section{References}

1. Yılmaz HB, Bolışık B. Nutrition in children. In: Conk Z, Başbakkal Z, Yılmaz Bal H, Bolışık B (eds). Pediatric Nursing. 1st edition. Ankara: Academician Medical Bookstore; 2018. p. 186- 216.

2. Seidell JC. The current epidemic of obesity. In: Bouchard C. (ed). Physical Activity and Obesity. 1st edition. Champaign, IL: Human Kinetics; 2000. p. 21-30.

3. The Global Health Observatory (GHO) is WHO's Portal Providing Access to Data and Analyses for Monitoring The Global Health Situation. 2016. [cited 19 February 2021]. Available from: http:// www.who.int/gho/en/2016.

4. Corsica JA, Hood MM. Eating disorders in an obesogenic environment. Journal of the American Dietetic Association 2011;111:996-1000.

5. Johnson R, Welk G, Maurice PFS, Ihmels M. Parenting styles and home obesogenic environments. International Journal of Environmental Research and Public Health 2012;9:1411-26.

6. Patrick H, Hennessy E, Mcspadden K, Oh A. Parenting styles and practices in children's obesogenic behaviors: Scientific gapsand future research directions. Childhood Obesity 2013; 9:73-86.

7. Menon V, Demeray MK. Child and adolescent social support scale for healty behaviors: Scale development and assesment of the relation between targeted social support and body size dissatisfaction. Children's Health Care 2013;42:45-66.

8. Kapinos KA, Yakusheva O, Eisenberg D. Obesogenic environmental influences on young adults: Evidence from college dormitory assignments. Economics and Human Biology 2014;12:98-109.

9. Kağıtçıbaşı Ç. People and People from Past to Present: Introduction to Social Psychology. 22nd edition. İstanbul: Evrim Publisher; 2019. p. 139.

10. Murphy M, Polivka B. Parental perceptions of the school's role in addressing childhood obesity. The Journal of School Nursing 2007;23:40-6.

11. Fahlman M, Dake J, McCaughtry N, Martin J. A pilot study to examine the effects of a nutrition intervention on nutrition knowledge, behaviors, and efficacy expecations in middle school children. Journal of School Health 2008;78:216-22.

12. Lee $\mathrm{P}, \mathrm{Lai}$ H, Chou Y, Chang L, Chang W. Perceptions of exercise in obese school-aged children. Journal of Nursing Research 2009; 17:170-6. 
13. Washington P, Reifsnider E, Bishop S, Ethington M, Ruffin $R$. Changes in family variables among normal and overweight preschoolers. Issues in Comprehensive Pediatric Nursing 2010;33:20-38.

14. Atlı M, Özkan Z, Uyar B. Assessment of obesity awareness stage of secondary school students. ERPA International Congresses on Education, 2-4 June 2016, Bosna-Hersek, Proceedings Abstract Book, s.200, 2016.

15. Sözen H, Bebek G. Determining the obesity awareness of university students. International Congress on Politic, Economic and Social Studies, 28-30 June 2018, Italy, Proceedings Abstract Book, 2018.

16. Yildız D, Fidancı BE, Suluhan D. Childhood obesity and prevention approaches. TAF Preventive Medicine Bulletin 2015;14:338-45.

17. Erdim L, Ergun A, Kuğuoğlu S. The role of nurses in the prevention and management of obesity in children. Journal of Health Science and Profession 2014;1:115-26.

18. Barbaros H, Balc1 S. The growing problem of children in globalized world: Obesity. Yıldırım Beyazıt University Journal of Nursing 2015;3:38-46.

19. Çapık C. Statistical power analysis and tt's use in nursing studies: Basic information. Journal of Anatolia Nursing and Health Sciences 2014;17:268-74.

20. Kafkas ME, Özen G. The Turkish adaptation of the obesity awareness scale: a validity and reliability study. Inonu University, Journal of Physical Education and Sport Sciences 2014;1:1-15.

21. Demir D, Bektaş M. The effect of childrens' eating behaviors and parental feeding style on childhood obesity. Eating Behaviors 2017;26:137-42.

22. Yayan EH, Çelebioğlu A. Effect of an obesogenic environment and health behaviour-related social support on body mass index and body image of adolescents. Global Health Promotion 2017;25:33-42.

23. Allen A. Effects of Educational Intervention on Children's Knowledge of Obesity Risk Factors (Ph.D. Thesis). Carroll College; 2011.
24. Yılmazbaș P, Gökçay G. Childhood obesity and its prevention, Journal of Child 2018;18:103-12.

25. Deleș B. Childhood obesity. Hacettepe University Faculty of Health Sciences Journal 2019;6:17-31.

26. Çınar S, Çavuşoğlu H. Research on obesity for children between the ages of 7-14 and from different socio-economic status. Turkiye Klinikleri Journal of Nursing Science 2016;8:112-21.

27. Özilbey P, Ergör G. Determining the prevalence of obesity in primary school students and eating habits in Izmir. Turkish Journal of Public Health 2015;13:30-9.

28. Drewnowski A. The economics of food choice behavior: why poverty and obesity are linked. Nestlé Nutrition Institute Workshop Series 2012;73:95-112.

29. Ludwig DS. Childhood obesity--the shape of things to come. New England Journal of Medicine 2007;357:2325-7.

30. Karaçil MŞ, Şanlıer N. Obesogenic environment and effects on the health. Gümüşhane University Journal of Health Sciences 2014;3:786-803.

31. Alphan E, Keskin Y, Tatlı F. Comparison of nutritional behaviour of adolescents in private and public school. Journal of Nutrition and Diet 2002;31:9-17.

32. Öztora S, Hatipoğlu S, Barutçugil B, Salihoğlu B, Yıldırım R, Şevketoğlu E. Estimating the prevalence of obesity and related risk factors for the primary school children. Medicine Journal of Bakirkoy 2006;2:11-4.

33. Kaşıkçı S. A Research on The Nutrition Habits of 6th,7th Ve 8th Grade Students in The Central Primary Schools of Edirne. (Master Thesis). Tekirdağ: Tekirdağ Namık Kemal University; 2010.

34. Drewnowski A, Rehm CD, Solet D. Disparities in obesity rates: analysis by zip code area. Social Science \& Medicine 2007;65:2458-63 